\title{
Prolactin release and milk removal induced by suckling and milking in lactating ewes is prevented by L-DOPA treatment
}

\author{
RP Deis ${ }^{1 *}$, G Kann 2, J Martinet 2 \\ 1 Laboratorio de Reproducion y Lactancia, Larlac-Cricyt, \\ Casilla de Correos 855, 5500 Mendoza, Argentina; \\ ${ }^{2}$ Laboratoire de Physiologie de la Lactation, INRA 78352, Jouy-en-Josas, Cedex France
}

(Received 13 April 1989; accepted 3 July 1990)

\begin{abstract}
Summary - The effect of L-DOPA on milk removal and on prolactin release during suckling or milking was studied in lactating ewes. Various doses of L-DOPA $(25,50,100$ and $200 \mathrm{mg}$ per animal) were injected iv 30 min before the suckling or milking period. Control ewes were injected with $0.9 \% \mathrm{NaCl}$ solution only. Milking induced a significant long-lasting release of prolactin.

An inhibition of milk removal was obtained with the dose of $200 \mathrm{mg}$ of L-DOPA. An inhibition of prolactin secretion was observed related to the dose of drug administered. The inhibitory effect of $200 \mathrm{mg}$ of L-DOPA on the secretion of prolactin after milking lasted for about $120 \mathrm{~min}$, and thereafter a significant increase in serum prolactin level occurred. This increase in serum prolactin was not due to a "rebound" effect of L-DOPA, since the milking stimulus had to be present to induce the delayed increase in prolactin. Doses of 25 or $50 \mathrm{mg}$ of L-DOPA prevented the surge of prolactin observed immediately after milking, but a long-lasting release of prolactin was obtained thereafter. The inhibitory effect of L-DOPA on prolactin release could be overridden by the suckling or milking stimuli according to the dose administered. The suckling stimulus was more effective than milking in overriding the inhibitory effect of the low dose of L-DOPA. The results indicate that milk removal and prolactin release induced by milking or suckling in lactating ewes is inhibited by an increase in monoamines at the hypothalamic-hypophyseal level.
\end{abstract}

\section{suckling / milking / prolactin / oxytocin / L-DOPA}

Résumé - Inhibition par la L-DOPA de la décharge de prolactine observée lors de la traite ou la tétée chez la brebis allaitante. Influence sur la production du lait. L'effet de l'administration aiguë de L-DOPA sur la traite et sur la décharge de prolactine observée lors de la stimulation mammaire est décrit chez la brebis en lactation. Des doses variables de L-DOPA $(25,50,100$ et $200 \mathrm{mg} /$ animal) sont administrées par voie iv 30 min avant la stimulation mammaire (traite ou allaitement). Les brebis «témoins" reçoivent au même moment, par la même voie, une solution de sérum physiologique. La traite, comme la tétée, sont à l'origine d'une importante décharge de prolactine d'assez longue durée. La dose de $200 \mathrm{mg}$ de L-DOPA diminue la quantité de lait obtenue tant à la traite que par la tétée de l'agneau. Une inhibition du réflexe de libération de la prolactine est observée, proportionnellement à la quantité de L-DOPA administrée. Elle dure au moins $2 \mathrm{~h}$ aprés l'application du stimulus dans le cas de l'administration de $200 \mathrm{mg}$ de L-DOPA. Ensuite se produit une élévation signi-

\footnotetext{
* Correspondence and reprints.
} 
ficative du taux de la prolactinémie, indépendante d'un phénomène de "rebond" éventuellement conséquence de linjection de L-DOPA, puisque pour observer ce phénomène, il faut qu'il y ait eu stimulation mammaire. Les doses de 25 et $50 \mathrm{mg}$ de L-DOPA inhibent la décharge de prolactine réflexe immédiatement après la traite uniquement dans sa composante d'amplitude sans en modifier la durée. L'effet inhibiteur de l'administration de L-DOPA sur la décharge de prolactine peut être modulé en fonction des doses de L-DOPA injectées par le stimulus résultant de la traite ou de la tétée. A cet égard, la tétée s'est révélée plus efficace que la traite. Cette expérimentation démontre que la quantité de lait obtenue après une traite ou une tétée, ainsi que la décharge de prolactine concomitante peuvent être inhibées par une augmentation de monoamines au niveau hypothalamo-hypophysaire.

allaitement / traite / prolactine / ocytocine / L-DOPA

\section{INTRODUCTION}

Hypothalamic catecholamines which are present at high concentrations have an important role in regulating the secretion of anterior and posterior pituitary hormones. Evidence for involvement of hypothalamic and hypophyseal dopamine in the regulation of prolactin and oxytocin release during suckling has been reported. Thus a clear inhibitory effect of dopamine on prolactin release has been observed in lactating animals (Davis and Borger, 1973; Prilusky and Deis, 1975; Deis and Prilusky, 1976; Cronin et al, 1978; Chiocchio et al, 1979). The effect of L-DOPA or dopamine on oxytocin release and milk removal is still controversial. Several authors have shown with meticulous methodology that centrally applied dopamine induces oxytocin release (Bridges et al, 1976; Clarke et al, 1979; Moss and Richard, 1979; 1982), while others administering L-DOPA to conscious rats observed an inhibition on the release of oxytocin and on milk removal (Prilusky and Deis, 1975; Seybold et al, 1978). On the other hand, bromocriptine, a dopaminergic agonist, did not affect oxytocin secretion in lactating rats (Russel et al, 1981).

The following experiments were undertaken to study the effect of the suckling or milking stimulus on prolactin release and on milk removal in ewes treated with L,3-4dihydroxyphenylalanine (L-DOPA).

\section{MATERIAL AND METHODS}

Primiparous lactating ewes (Prealpes du Sud) were used from 20 days up to 3 months after parturition. The ewes nursed their lambs for at least 4 weeks. Milked ewes were used between 30-90 days after parturition. The average days postpartum did not differ among the different milked groups. In the experiments in which the effect of the suckling stimulus was studied, the mother was isolated from the lamb from 10.00 until $14.00 \mathrm{~h}$. The same interval was established in the milked group. Before being returned to the lactating ewe, the lamb was weighed and then allowed to suckle for $5 \mathrm{~min}$. The lamb was then reweighed and the gain in weight during the time of suckling was taken as an index of the amount of milk removed from the mother. Handmilked lactating ewes were each milked for 5 $\min$ at $14.00 \mathrm{~h}, 4 \mathrm{~h}$ after the first milking in the morning at $10.00 \mathrm{~h}$. The amount of milk obtained was recorded.

To obtain a central effect of dopamine which does not cross the blood-brain barrier, various doses of its precursor, L-DOPA $(25,50,100$ and $200 \mathrm{mg} /$ animal), dissolved in $0.9 \% \mathrm{NaCl}$ solution were injected iv (jugular vein) $30 \mathrm{~min}$ before the suckling or milking period. The injection was followed or not by suckling or milking. Control ewes were injected with saline only. Blood samples were obtained from the jugular vein 5 $\min$ before and $5,30,60,90,120,180$ and 210 $\mathrm{min}$ after the suckling or milking period. 
Serum prolactin was measured by radioimmunoassay according to the method previously described (Kann, 1971). The results of the prolactin determination are expressed in $\mathrm{ng} / \mathrm{ml}$ of PS7 NIH $(24 \mathrm{IU} / \mathrm{mg})$. The variation between controls and L-DOPA-treated groups was determined by one-way analysis of variance and Student's $t$ test.

\section{RESULTS \\ Effects of L-DOPA administration on prolactin release}

In 18 control ewes milked for 5 min, serum prolactin increased from $45 \pm 5 \mathrm{ng} / \mathrm{ml}$ (pre-milking values) to $215 \pm 32 \mathrm{ng} / \mathrm{ml}$ $(P<0.001)$ and the levels remained significantly higher than the pre-milking values until $90 \mathrm{~min}$ after $(P<0.001$ at $30 \mathrm{~min}$, $P<0.01$ at $60 \mathrm{~min}$, and $P<0.01$ at 90 min). As shown in figure 1 , in 16 ewes the normal release of prolactin induced by milking was prevented by L-DOPA (200 $\mathrm{mg}$ ) during the first $90 \mathrm{~min}$ after milking. Serum prolactin levels were not significantly different from the pre-milking values. However, a significant increase in serum prolactin concentration was obtained at 180 and $210 \mathrm{~min}(P<0.01)$. L-DOPA also significantly reduced the pre-milking serum prolactin values $(P<0.001)$. In lactating ewes treated with L-DOPA but without milking following injection, the serum prolactin level was at none of the times studied, significantly higher than the mean value in control ewes before milking, and no peaks were observed. No differences in serum prolactin were found at 180 and 210 min between the non-milked L-DOPAtreated group and the control milked ewes (see fig 1). A dose of $50 \mathrm{mg}$ of L-DOPA administered to 6 ewes prevented the release of prolactin only 5 min after milking, but a significant increase occurred during

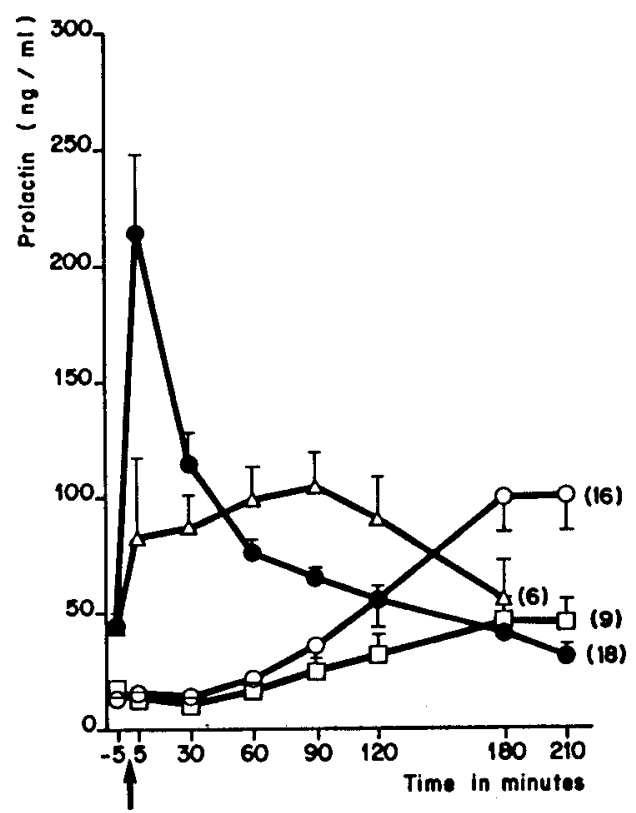

Fig 1. Mean \pm SEM serum prolactin concentrations in untreated laciating ewes (O) before and after a 5-min milking period and in milked ewes treated with $50 \mathrm{mg}(\Delta)$ or $200 \mathrm{mg}$ L-DOPA with $(O)$ or without (D) a milking stimulus. The number of ewes in each group is shown in parentheses.

the following $120 \mathrm{~min}(P<0.025$ at $30 \mathrm{~min}$, $P<0.001$ at 60 and $90 \mathrm{~min}$ and $P<0.025$ at $120 \mathrm{~min}$ ), when compared to the premilking value. However, this dose of $\mathrm{L}$ DOPA did not significantly reduce the premilking prolactin concentration. In a group of 10 lactating ewes, the dose of $25 \mathrm{mg}$ of L-DOPA did not affect the total release of prolactin induced by milking but altered the profile of the curve (fig 2). Thus, $5 \mathrm{~min}$ after milking, the prolactin peak was significantly lower than the peak in the nontreated milked ewes $(P<0.001)$ but the summation of the amount of prolactin released in the different periods $1+5$ to 210 


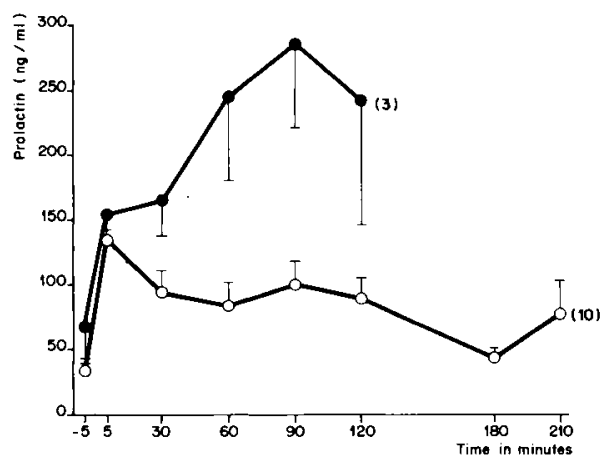

Fig 2. Effect of $25 \mathrm{mg}$ L-DOPA given by iv injection 30 min before the 5-min period of suckling $(O)$ or milking $(O)$ on serum prolactin concentration (Mean \pm SEM) in lactating ewes. The number of ewes in each group is shown in parentheses.

$\mathrm{min}$ ) showed similar values in both groups (control = 598.8 ng; L-DOPA $25 \mathrm{mg}=$ $626.4 \mathrm{ng}$ ).

The surge in serum prolactin in groups of 3 suckling or 10 milked ewes was not different 5 and $30 \mathrm{~min}$ after the stimulus (fig 2). The prolactin levels were increased from pre-suckling values and continued to rise up to $120 \mathrm{~min}$ after suckling. A significant difference in serum prolactin concentration was found at $60 \mathrm{~min}$ $(P<0.05)$ and $90 \mathrm{~min}(P<0.01)$ between the suckled and milked groups treated with $25 \mathrm{mg}$ of L-DOPA.

\section{Effect of L-DOPA on milk removal (fig 3)}

No difference was observed in the amount of milk obtained by the lamb during a 5min suckling period in a group of control lactating ewes during 3 consecutive days. The administration of $100 \mathrm{mg}$ of L-DOPA did not affect milk removal. The dose of

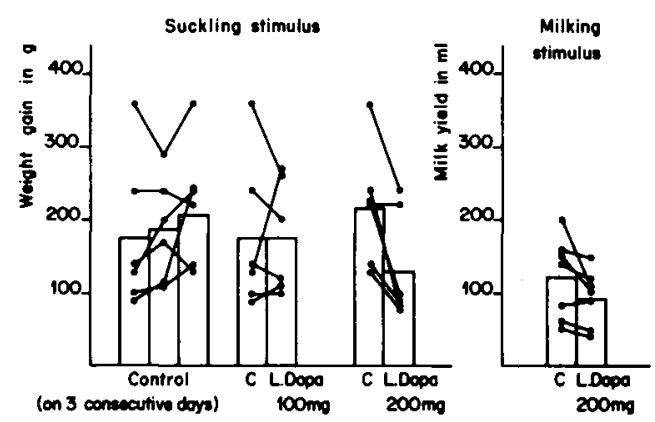

Fig 3. Effect of L-DOPA ( $100 \mathrm{or} 200 \mathrm{mg}$ ) on the amount of milk obtained from lactating ewes during 5 min of suckling or milking. As each lactating ewe served as its own control, lines joining the values obtained as control (C) or LDOPA treatment indicate the individual variations in weight gain. Each column represents the mean weight gain of the lambs during $5 \mathrm{~min}$ suckling or the mean milk yield after a 5-min milking period.

$200 \mathrm{mg}$ of L-DOPA caused a significant inhibition of milk removal in the suckled $(P<$ $0.01)$ and milked group $(P<0.05)$ (paired Student's $t$ test).

\section{DISCUSSION}

The present results show that milking induced a significant long-lasting release of prolactin. This prolactin surge was prevented by different doses of L-DOPA, this inhibition being related to the dose of drug administered. The inhibitory effect of different catecholamines on prolactin release has been demonstrated by experiments in vivo and in vitro (Donoso and Bishop, 1971; Davis and Borger, 1973; Prilusky and Deis, 1975; Deis and Prilusky, 1976; Chiocchio et al, 1979).

As shown in figure 1 , the inhibitory effect of L-DOPA (200 mg) on the secretion 
of prolactin after milking lasted for about $120 \mathrm{~min}$, and thereafter a significant increase in serum prolactin concentration occurred. The doses of 25 and $50 \mathrm{mg}$ of LDOPA prevented the prolactin peak observed 5 min after milking in the control ewes. However, after the initial inhibition, a significant long-lasting release of prolactin was obtained with both dosages of L-DOPA $(30,60,90$ and $120 \mathrm{~min}$ after milking).

The pre-milking level of serum prolactin concentration was significantly lowered only by the large dose of L-DOPA administered $25 \mathrm{~min}$ before. The effect obtained by treating non-milked lactating ewes with $200 \mathrm{mg}$ of L-DOPA may prove that the surge of serum prolactin observed after the effect of L-DOPA had passed was not due to a secondary effect of L-DOPA at the hypothalamic or pituitary level. It is clear that the milking stimulus must be present to induce the delayed increase in serum prolactin values. It is known that the nursing stimulus in lactating rats decreases hypothalamic prolactin inhibitory factor activity and pituitary dopamine levels (Minaguchi and Meites, 1967; Chiocchio et al, 1979). On the other hand, it has been proposed that L-DOPA or dopamine may exert a dual inhibitory control over prolactin release by stimulating the release of prolactin inhibiting factor from the median eminence and by acting directly on the gland to suppress prolactin release (Ojeda et al, 1974). In the present study the stimulating action of milking and suckling may have overidden the inhibitory effect of L-DOPA on prolactin release.

If L-DOPA acts by itself of after conversion to dopamine at both the hypothalamic and pituitary level, it is possible that LDOPA prevented the release of prolactin from the pituitary but did not affect at the central nervous system level the action of the nursing stimulus which is still able to induce prolactin release at the time the pituitary is freed of the monoamine influence.
We must also consider that the monoamine oxidase activity present in the pituitary gland may favour the transient nature of the catecholamine effect. On the other hand, experiments in vitro have shown that the pituitary may rapidly recover its capacity to release prolactin when it is transferred from a medium containing catecholamines to a catecholamine-free medium (MacLeod and Lehmeyer, 1972).

As shown in figure 2, the suckling stimulus is more potent than milking in overriding the inhibitory effect of L-DOPA. In the ewes treated with $25 \mathrm{mg}$ of L-DOPA, the suckling stimulus by one lamb induced a 2-3-fold increase in prolactin release during the following $120 \mathrm{~min}$ when compared to the amount of prolactin released by milking.

As with prolactin, milk removal induced by suckling or milking was also prevented by the high dose of L-DOPA. There appears to be a peripheral neural control of the mammary structures, especially in larger animals and this control is in part adrenergic. Two hundred $\mathrm{mg}$ dosage of $\mathrm{L}$ DOPA may well have influenced this peripheral mechanism controlling the ability to remove milk from the mammary gland.

In our experiments, the effect of LDOPA on milk removal and on prolactin release is probably mediated through dopamine, considering the $30 \mathrm{~min}$ delay between L-DOPA administration and the milking or suckling period. Observations made by Glowinsky (1970) on L-DOPA metabolism may indicate that in the present studies the decrease in serum prolactin and milk removal takes place at a time when only the levels of dopamine in the central nervous system are elevated. We have no evidence indicating whether LDOPA acts at the hypothalamic or the hypophyseal level. A binding site with characteristics of the dopamine receptors has been described in the anterior and posterior pituitary of sheep (Cronin et al, 1978). 
The present findings correlate well with previous results obtained in lactating rats (Prilusky and Deis, 1975; Deis and Prilus$k y, 1976)$ and indicate that the monoamines are involved in the mechanisms of control of prolactin release and probably of milk removal in lactating ewes.

\section{ACKNOWLEDGMENTS}

The skillful technical assistance of Ms J Paly and $C$ Meusnier is greatly acknowledged.

\section{REFERENCES}

Bridges TE, Hillhouse EW, Jones MT (1976) The effect of dopamine on neurohypophyseal hormone release in vivo and from the rat neural lobe and hypothalamus in vitro. J Physiol 260, 647-666

Chiocchio SR, Cannata MA, Cordero-Funes JRC, Tramezzani JH (1979) Involvement of adenohypophyseal dopamine in the regulation of prolactin release during suckling. Endocrinology 105, 544-547

Clarke G, Lincoln DW, Merrick LP (1979) Dopaminergic control of oxytocin release in lactating rats. $J$ Endocrinol $83,409-420$

Cronin MJ, Roberts JM, Weiner RI (1978) Dopamine and dehydro-ergocryptine binding to the anterior pituitary and other brain areas of the rat and sheep. Endocrinology 103, 302309

Davis SL, Borger ML (1973) Hypothalamic catecholamine effects on plasma levels of prolactin and growth hormone in sheep. Endocrinology 92, 303-309

Deis RP, Prilusky J (1976) Prolactin release induced by suckling in lactating rats after LDOPA treatment. J Reprod Fertil 46, 265 267
Donoso A, Bishop W (1971) Accion de precursores $\mathrm{e}$ inhibidores de la sintesis de catecolaminas sobre la secrecion de prolactina en ratas con lesion en la eminencia media. Rev Soc Argent Biol 47, 117-121

Glowinsky $J$ (1970) Metabolisme des monoamines dans les systèmes de neurones aminergiques centraux. 33-48. In: Neuroendocrinologie (Kordon C, Benoît J, eds) CNRS Paris, Colloque National $n^{\circ}$ 927, 33-48

Kann G (1971) Dosage radio-immunologique de la prolactine plasmatique chez les ovins. $C R$ Hebd Seanc Acad Sci Paris 272, 2808-2811

Mac Leod RM, Lehmeyer JD (1972) Regulation of the synthesis and release of prolactin. In: Lactogenic Hormones (Wolstenholme GEW, Knight J, eds) Ciba Foundation Symp, Churchill Livingstone, London, 53-76

Minaguchi $H$, Meites J (1967) Effects of sucking on hypothalamic LH-releasing factor and prolactin inhibiting factor, and on pituitary $\mathrm{LH}$ and prolactin. Endocrinology 80, 603-607

Moos F, Richard P (1979) Effects of dopaminergic antagonists and agonists on oxytocin release induced by various stimuli. Neuroendocrinology 28, 138-144

Moos F, Richard P (1982) Excitatory effect of dopamine on oxytocin and vasopressin reflex releases in the rat. Brain Res 241, 249-260

Ojeda SR, Harms PG, McCann SM (1974) Effect of blockage of dopamine receptors on prolactin and $\mathrm{LH}$ release: median eminence and pituitary site of action. Endocrinology 94, 1650-1657

Prilusky J, Deis RP (1975) Effect of L-DOPA on milk ejection and prolactin release in lactating rats. $J$ Endocrinol 67, 397-401

Russell JA, Harrisson DJ, McNeylly AS (1981) Bromocriptine and alpha-ergocryptine do not inhibit oxytocin secretion in the lactating rat. $J$ Endocrinol 89, 91-98

Seybold VS, Miller JW, Lewis PR (1978) Investigation of a dopaminergic mechanism for regulating oxytocin release. J Pharmacol Exp Ther 207, 605-610 